\section{Díaz Carlos}

\section{6}

\section{La Virtud de la Fortaleza}

\section{Trillas}

México

\section{L.F. Joaquín Zamora Núñez ${ }^{1}$}

El autor aborda la virtud de la fortaleza. Virtud que se va adquiriendo a sazón de otras muchas, pues, cuando se busca crecer en una, al mismo tiempo se crece en todas. Solo que ésta se presenta como base y continuidad de aquellas. Para ello, Carlos Díaz, traza en su obra un camino, en siete capítulos, para poder asimilarla desde lo exterior hacia lo interior.

Partiendo de la fuerza del propio testimonio, del ejemplo de vida, que deja una impronta en las personas, abriéndose a un espacio cada vez más amplio. Pues un buen ejemplo es digno de «contagiarlo», de alcanzar cada día a más y más personas, en una palabra: de universalizarlo.

Así al universalizar la virtud de la fortaleza, surge de ella, como argumento lógico la acción del «deber», es decir, la respuesta subjetiva a ese valor de lo universal. Valor que para hacerlo crecer, tiene que ser ejercitado de modo positivo, es decir, querer alcanzar y poseer dicho bien de manera constante.

A esta virtud le viene añeja otras más: la magnanimidad, la magnificencia, la generosidad, la superación, etc., que le darán sustento y estructura y así poder responder puntualmente a los desafíos del tiempo presente.

La belleza de este libro radica en su simplicidad, en los innumerables ejemplos de hombres y hechos virtuosos; pero también, en que

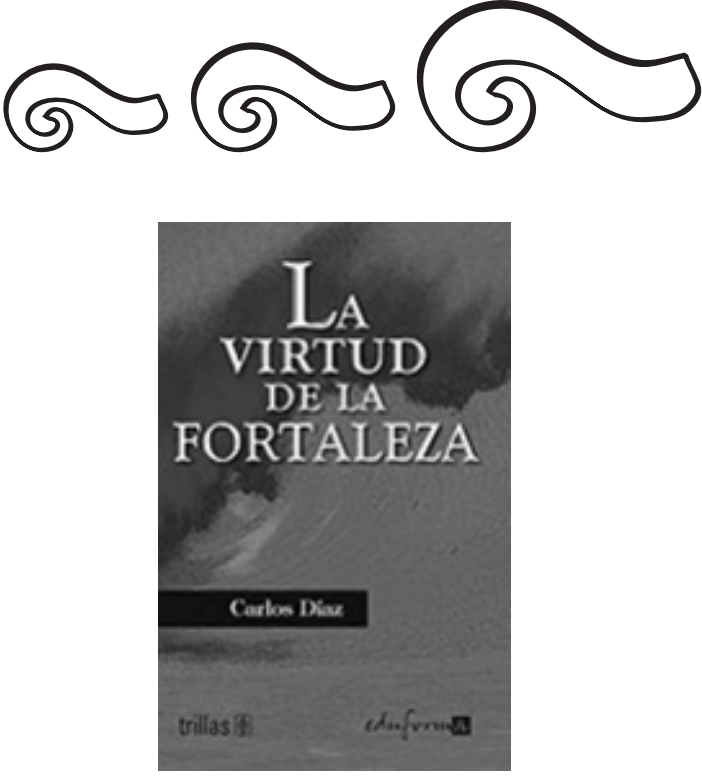

no se «tropieza» en explicaciones efímeras y grotescas. Lectura amena, grata y ágil. Es la forma como va haciendo fluir con su tinta la inteligencia de su obra.

Frente a una sociedad y un tiempo en el cual, lo fácil, lo efímero, lo caduco es lo «in»; el autor nos presenta la virtud de la fortaleza como una grandeza en sí misma que conduce a la perfección de lo humano y, por ende, de nuestra sociedad.

1 Catedrático Universidad La Salle Pachuca, jzamora@lasallep.edu.mx 


$$
\beta
$$

